\title{
AL amyloidosis that presented with marked hepatomegaly and polyclonal hypergammaglobulinemia
}

\author{
Hitoshi Ohno ${ }^{1 *}$, Yusuke Toda ${ }^{1}$, Yoshimasa Kamoda ${ }^{1}$, Makoto Okabe ${ }^{2}$, Gen Honjo ${ }^{3}$ \\ ${ }^{1}$ Department of Hematology, Tenri Hospital; ${ }^{2}$ Department of Gastroenterology, Tenri Hospital; ${ }^{3}$ Department of Diagnostic \\ Pathology, Tenri Hospital
}

Received 2017/4/22; accepted 2017/5/16; released online 2017/7/1

A 65-year-old woman presented with marked hepatomegaly and polyclonal hypergammaglobulinemia. Her total serum protein was $8.9 \mathrm{~g} / \mathrm{dL}$ with $35.6 \%$ albumin and $40.2 \%(35.8 \mathrm{mg} / \mathrm{mL}) \gamma$ globulin. Alkaline phosphatase was $730 \mathrm{IU} / \mathrm{L}$. The cranio-caudal liver span measured on computed tomography was $24.2 \mathrm{~cm}$. A biopsy of the liver revealed replacement of the liver parenchyma with amorphous eosinophilic materials that were stained positive with Congo red and showed the apple-green birefringence of amyloid; amyloid deposits were also observed in the gastric mucosa and bone marrow (BM). Although immunofixation of the serum and urine detected no monoclonal component, the serum free light chain (FLC) assay revealed an excess

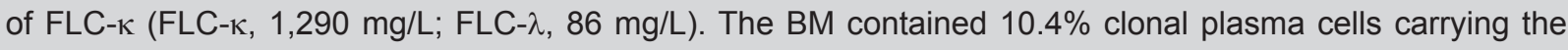
CCND1-immunoglobulin heavy chain fusion gene. She was diagnosed with $\mathrm{AL}$ amyloidosis and treated with bortezomib-based chemotherapy, readily leading to the hematological response fulfilling the criteria of very good partial response. The hepatomegaly was steadily resolved in response to persistent administration of bortezomib for $>2$ years. It is possible that the hypergammaglobulinemia reflected a reactive process against amyloid deposits in the liver. This report suggests that plasma cell-targeting therapy can reduce the amyloid deposits from the involved organs, potentially reversing their dysfunction.

Keywords: AL amyloidosis, hepatic amyloidosis, serum free light chain, polyclonal hypergammaglobulinemia, bortezomib-based chemotherapy

\section{INTRODUCTION}

Immunoglobulin light chain (AL) amyloidosis is a clonal plasma cell disorder characterized by tissue deposits of light chain protein, leading to dysfunction of vital organs. ${ }^{1-3}$ Cardiac and renal involvements of $\mathrm{AL}$ amyloidosis are well recognized, and the disease is considered in the differential diagnosis when a patient

*Correspondence to: Hitoshi Ohno, MD, PhD

Department of Hematology, Tenri Hospital

200 Mishima, Tenri, Nara 632-8552, Japan

e-mail: hohno@tenriyorozu.jp presents with cardiomegaly or nephrotic syndrome. ${ }^{2,4}$ In contrast, dominant hepatic involvement as the presenting sign or symptom is unusual. ${ }^{4}$ Nevertheless, the liver is palpable in 25 to $30 \%$ of patients with $\mathrm{AL}$ amyloidosis and the most frequently abnormal test of hepatic function is an elevated serum alkaline phosphatase (ALP) level; ${ }^{1,3,4}$ the criterion of hepatic involvement is a liver span $>15 \mathrm{~cm}$ in the absence of heart failure or ALP $>1.5$-times the institutional upper limit of normal. ${ }^{5}$ The outcome of patients with hepatic amyloidosis was reported to be dismal; the median survivals of the 80 
and 98 patients in the Mayo clinic series were 9 and 8.5 months, respectively. ${ }^{6,7}$ A literature review found that patients may present with severe hepatomegaly, intrahepatic cholestasis, or florid liver failure. ${ }^{8-13}$

In up to $90 \%$ of patients with AL amyloidosis, a monoclonal protein is detectable in the serum and/or urine by routine protein electrophoresis or immunofixation. ${ }^{3,4} \mathrm{Ex}-$ amination of the bone marrow (BM) reveals monoclonal plasma cells, even though the clonal plasma cell burden is small (i.e. median infiltration of 7 to $10 \%$ ), ${ }^{1,2,4}$ compared with that in symptomatic multiple myeloma.

We report here a patient with AL amyloidosis who presented with marked hepatomegaly. Intriguingly, the serum protein electrophoresis revealed polyclonal hypergammaglobulinemia with polyclonal increase of immunoglobulins instead of the presence of monoclonal component with decreased residual immunoglobulins, delaying the correct diagnosis.

\section{CASE PRESENTATION}

A 65-year-old woman, who had been treated for compression fracture of the L2 lumbar vertebra at an orthopedic clinic, was referred to the Department of Hematology of our hospital with the suspicion of a hematological malignancy due to leukocytosis and hypergammaglobulinemia. On examination, the liver was markedly enlarged at 10-finger-width below the right costal margin to reach the level of anterior iliac spine, and was firm with a dull edge and smooth surface, and was non-tender. There was no ascites or leg edema.

The hemoglobin level was $12.9 \mathrm{~g} / \mathrm{dL}$, white blood cell count $14.18 \times 10^{3} / \mu \mathrm{L}$, and platelet count $257 \times 10^{3} /$ $\mu \mathrm{L}$. The white cell differential was $31.5 \%$ lymphocytes, $6.5 \%$ monocytes, $0.5 \%$ eosinophils, $1.0 \%$ basophils, $57.5 \%$ segmented neutrophils, and $3.0 \%$ banded neutrophils. Red cells exhibited rouleaux formation, and Howell-Jolly bodies were seen. Total serum protein was $8.9 \mathrm{~g} / \mathrm{dL}$, albumin $3.2 \mathrm{~g} / \mathrm{dL}$, lactate dehydrogenase $256 \mathrm{IU} / \mathrm{L}$, aspartate aminotransferase $46 \mathrm{IU} / \mathrm{L}$, alanine aminotransferase $13 \mathrm{IU} / \mathrm{L}$, total bilirubin $2.3 \mathrm{mg} / \mathrm{dL}, \gamma$ glutamyl transpeptidase 274 IU/L, ALP 730 IU/L (reference range, 100 to $335 \mathrm{IU} / \mathrm{L})$, choline esterase $146 \mathrm{IU} / \mathrm{L}$, blood urea nitrogen $12.0 \mathrm{mg} / \mathrm{dL}$, creatinine $0.7 \mathrm{mg} / \mathrm{dL}$, uric acid $6.8 \mathrm{mg} / \mathrm{dL}$, and C-reactive protein $0.5 \mathrm{mg} / \mathrm{dL}$. Serum protein electrophoresis showed the polyclonal hypergammaglobulinemia pattern with $35.6 \%$ albumin, $3.4 \% \alpha 1$ globulin, $6.4 \% \alpha 2$ globulin, $14.5 \% \beta$ globulin, and $40.2 \%(35.8 \mathrm{mg} / \mathrm{mL}) \gamma$ globulin. The level of $\mathrm{IgG}$ was $3,150 \mathrm{mg} / \mathrm{dL}$, IgA was $1,289 \mathrm{mg} / \mathrm{dL}$, and $\operatorname{IgM}$ was $203 \mathrm{mg} / \mathrm{dL}$. Computed tomography (CT) of the body with the administration of contrast material demonstrated marked hepatomegaly with homogeneous contrast enhancement; the cranio-caudal liver span was $24.2 \mathrm{~cm}$ (Figure 1A). The size of the spleen was normal.

The patient was admitted to another hospital, where she developed hematemesis due to multiple gastric ulcers; she was then transferred to the Department of Gastroenterology of our hospital. CT scan of the whole body disclosed pneumonia, pleural fluids, and ascites, in addition to the marked hepatomegaly. Evaluation of blood flow with pulsed and color Doppler ultrasonography revealed reverse flow at the portal trunk, splenic vein, and superior mesenteric vein. Prothrombin time was 17.0 sec. Serology of the hepatitis B and C virus antigens was negative.

A biopsy of the liver through percutaneous fine-needle approach revealed replacement of the liver parenchyma with amorphous eosinophilic materials (Figure 1B). The materials were stained positive with Congo red staining, and the Congo red-stained materials exhibited the apple-green birefringence of amyloid under polarizing light microscopy. An upper gastrointestinal endoscopy revealed grade 0 to 1 esophageal varices at the lower esophagus, and biopsies of the gastric mucosa revealed Congo red-stained amyloid deposits with characteristic birefringence (Figure 2).

Immunofixation tests of the serum and urine detected no monoclonal component (Figure 3A). However, the serum free light chain (FLC) assay revealed an excess of

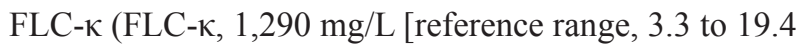




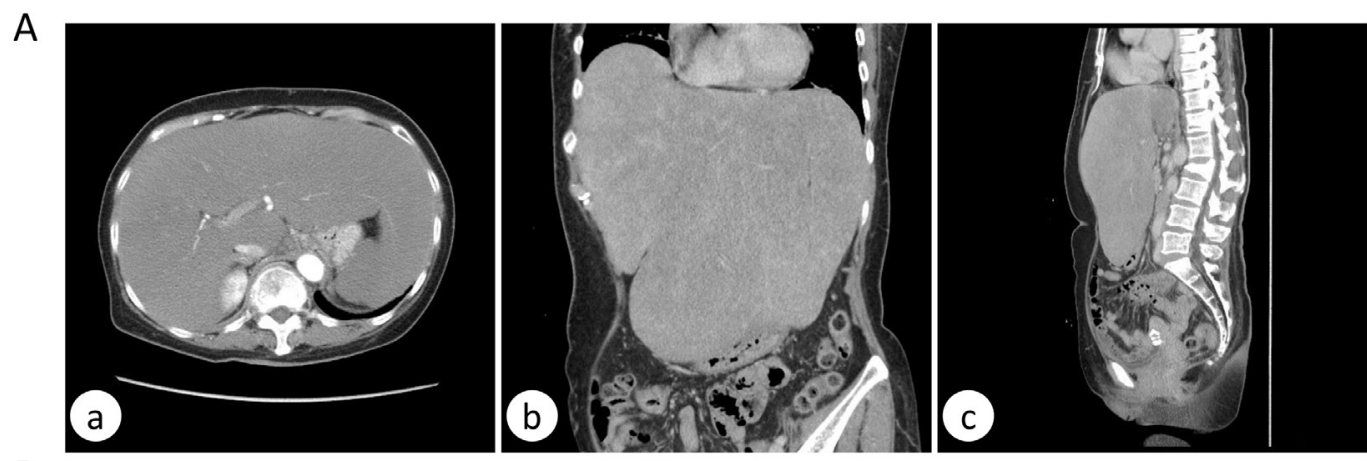

B
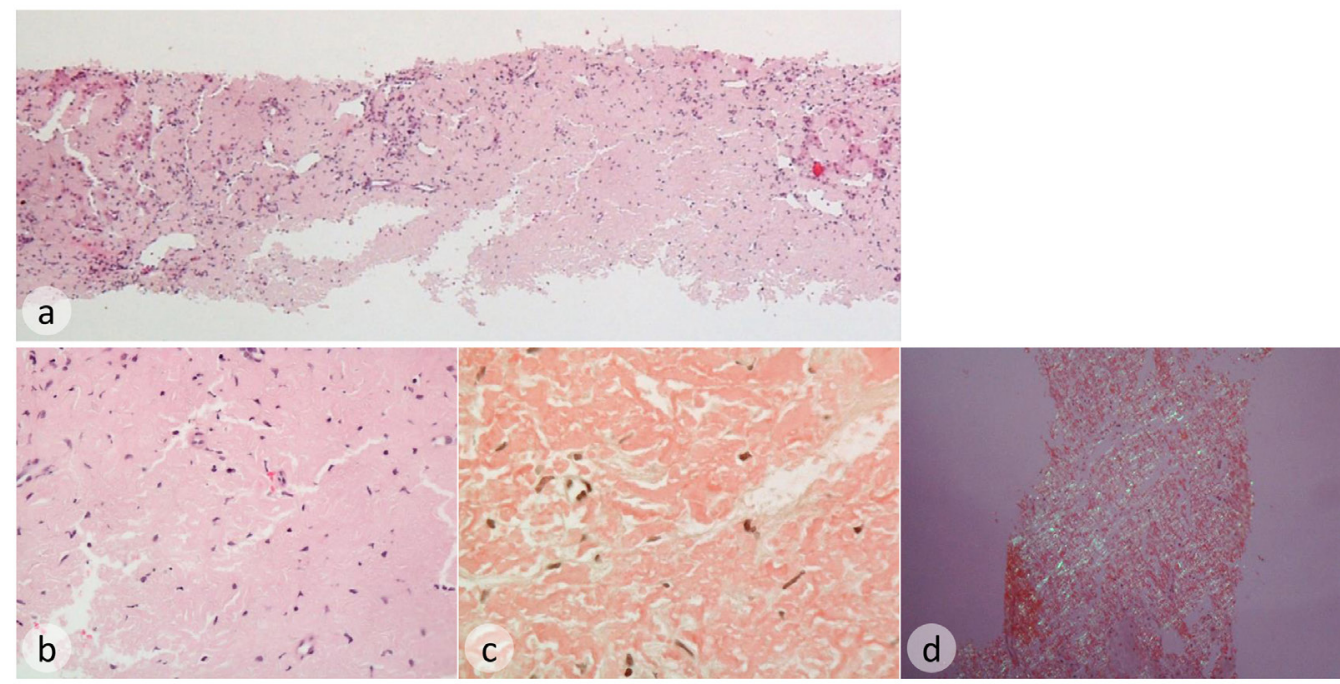

Figure 1. Liver involvement of AL amyloidosis. (A) Transverse (a), coronal (b), and sagittal (c) CT images at presentation, exhibiting marked hepatomegaly. The craniocaudal liver span was $24.2 \mathrm{~cm}$. The sagittal plane image shows wedge compression fracture of the $\mathrm{L} 2$ lumbar spine. The Th12 thoracic spine may have been affected. (B) Biopsy of the liver, showing deposits of amyloid: a, loupe image of the biopsy specimen (Hematoxylin and eosin [H\&E] staining); $b$, higher magnification picture (H\&E staining); $c$, Congo red staining; and $d$, polarizing light microscopy image.

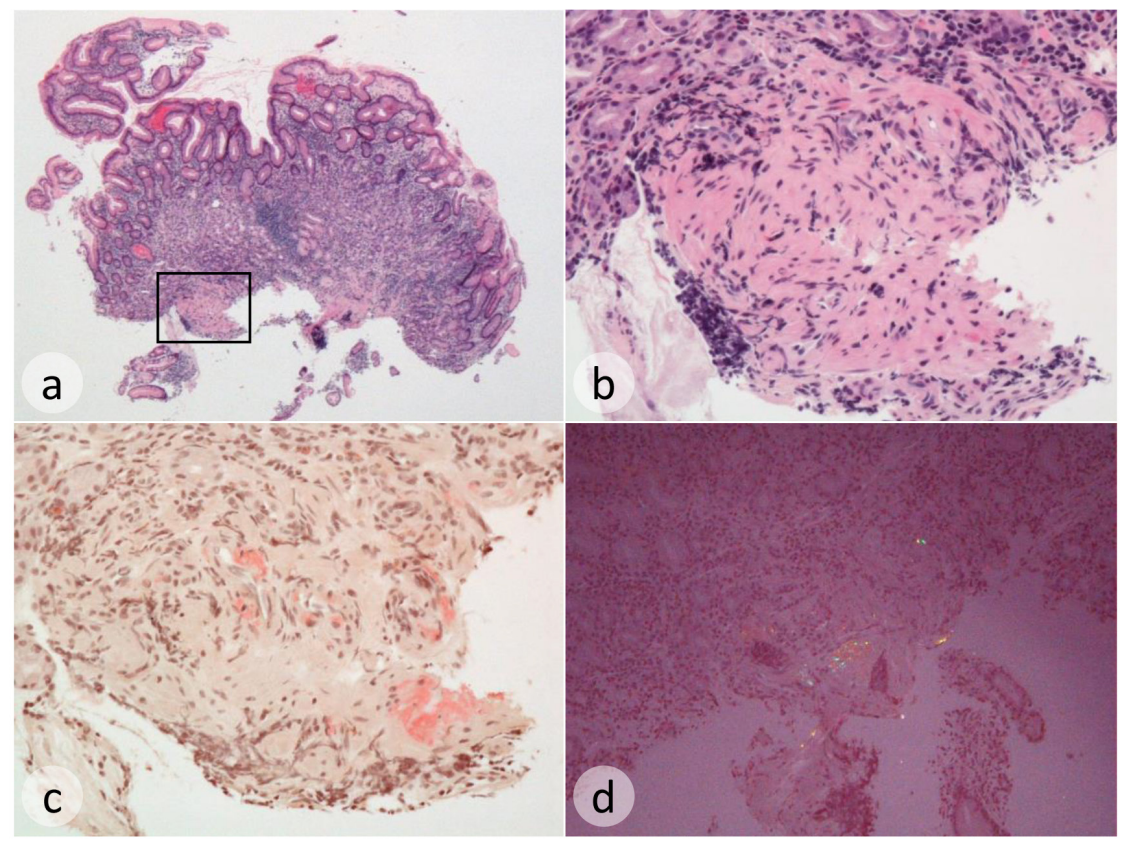

Figure 2. Amyloid deposits in the gastric mucosa. $a$, loupe image of a biopsy specimen; $b$, higher magnification of the area enclosed by the rectangle in $a$, focusing upon the amyloid deposits; $c$, Congo red staining; and $d$, polarizing light microscopy image. 
$\mathrm{mg} / \mathrm{L}]$; FLC- $\lambda$, $86 \mathrm{mg} / \mathrm{L}$ [5.7 to $26.3 \mathrm{mg} / \mathrm{L}]$; FLC ratio, 15.00 [0.26 to 1.65$])$. The BM biopsy revealed that the inter-trabecular space was filled with amyloid deposits of identical features with those of the liver (Figure 3B, $a$ to $d$ ). Examination of the BM aspiration smear detected plasma cells comprising $10.4 \%$ of the nucleated cells (Figure 3B,e), and the cells were CD19- ${ }^{-}$CD20 $0^{\mathrm{dim}}$,

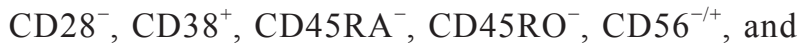
CD $138^{+}$, and showed cytoplasmic immunoglobulin $\kappa$ light-chain restriction by multicolor flow cytometry (Figure 4). The plasma cells carried the CCND1-immunoglobulin heavy chain $(I G H)$ fusion gene by fluorescence in situ hybridization (FISH) of the interphase nuclei (Figure 3B, f). $\beta 2$ microglobulin was $4.13 \mu \mathrm{g} / \mathrm{mL}$. Brain natriuretic peptide (BNP) was 180.0 pg/mL (reference, $<18.4 \mathrm{pg} / \mathrm{mL}$ ).

\section{TREATMENT AND COURSE}

We finally made the diagnosis of AL amyloidosis involving the liver, stomach, and BM. No cardiac abnormality was found by echocardiography. We treated the patient with bortezomib and low-dose dexamethasone in combination with or without cyclophosphamide (i.e. $\mathrm{CBd}$ or $\mathrm{Bd}$ regimen). The course was complicated by aspiration pneumonia due to prolonged bedrest, bleeding from rupture of esophageal varices, and severe pain and impaired physical activity due to additional vertebral compression fractures. Nevertheless, the values of IgG and IgA readily fell to the normal levels, and polyclonal hypergammaglobulinemia was resolved after the first cycle of $\mathrm{CBd}$ (Figure 5). The serum FLC $\kappa / \lambda$ ratio also decreased, but remained higher than the reference range. Hepatomegaly was steadily resolved in response to per-

A
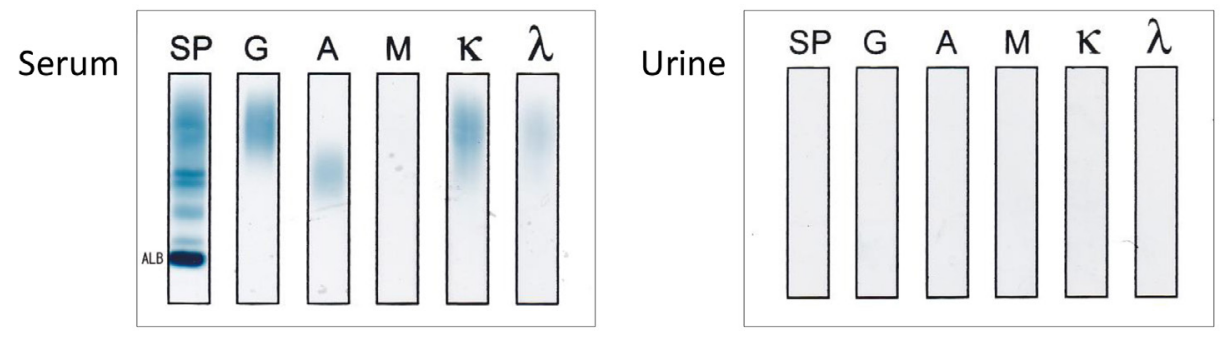

B

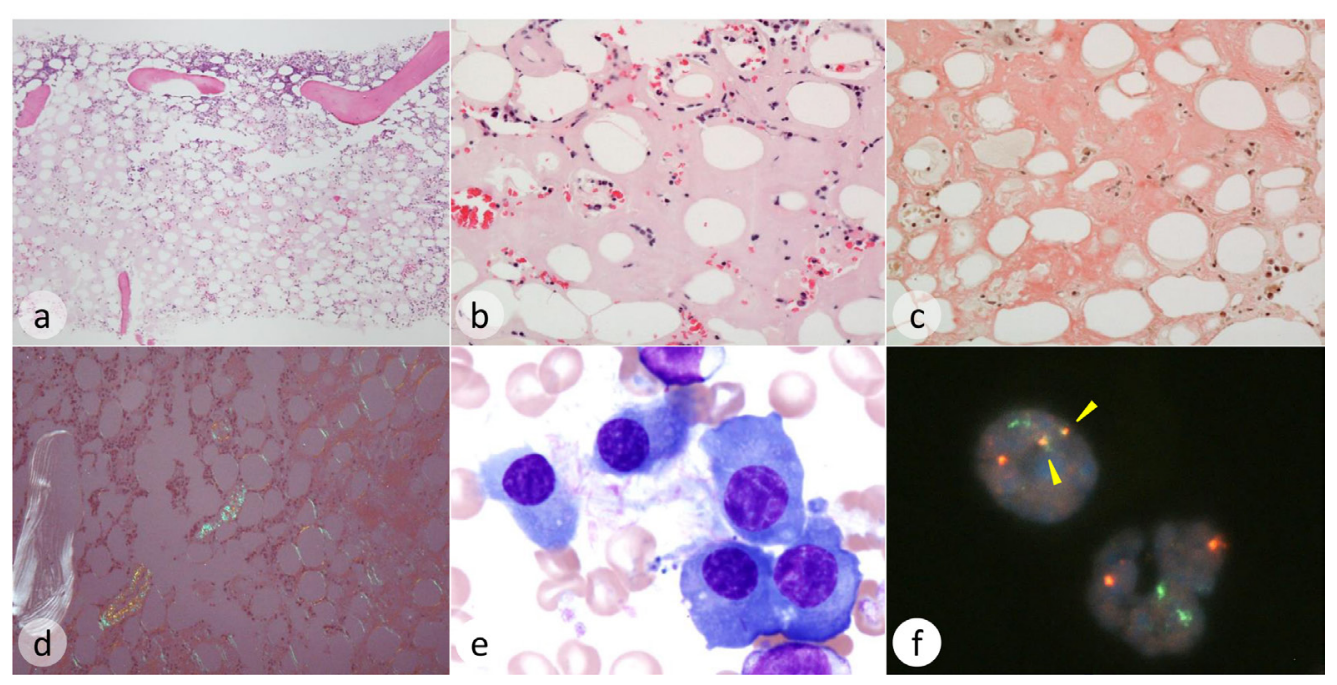

Figure 3. Investigation of clonal plasma cells. (A) Immunofixation tests of the serum and urine showing the absence of monoclonal component but a polyclonal gammopathy pattern of the serum. (B) Amyloid deposits in the BM and features of clonal plasma cells: a, lower magnification picture of the biopsy specimen (H\&E stain); $b$, higher magnification picture (H\&E staining); $c$, Congo red staining; $d$, polarizing light microscopy image; $e$, plasma cells on the BM smear slide (Wright staining, $\times 100$ objective lens); and $f$, nuclear FISH using the dual-color, dual-fusion probe composed of red-labeled CCND1 and green-labeled IGH. Two fusion signals are indicated by yellow-colored arrowheads (top left). 


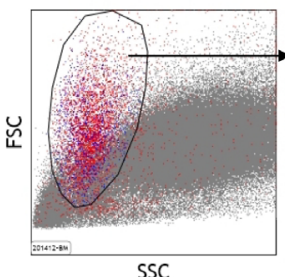

SSC
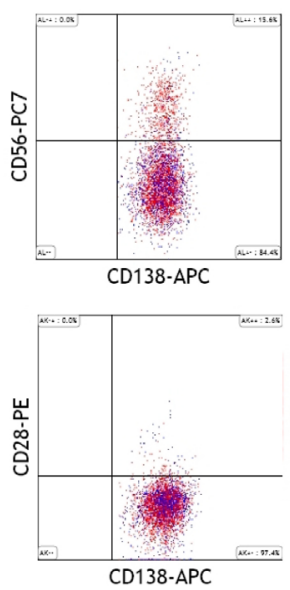

CD138-APC

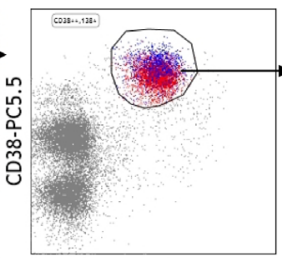

CD138-APC
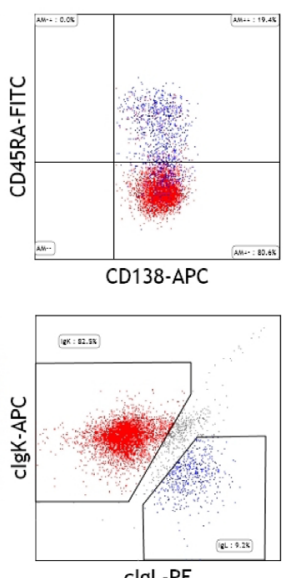

clgL-PE

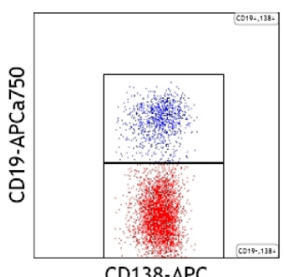

CD138-APC

Figure 4. Multicolor flow cytometry of plasma cells in the BM. The CD138 ${ }^{+}$and $\mathrm{CD} 38^{+}$cells were separated into $\mathrm{CD} 19^{-}$(red color) and $\mathrm{CD} 19^{+}$(blue color) fractions. The CD19- and CD138 ${ }^{+}$cells were $\mathrm{CD}^{-} 6^{-/+}, \mathrm{CD} 45 \mathrm{RA}{ }^{-}$, CD45RO- ${ }^{-}, C_{20}{ }^{\text {dim }}$, and $\mathrm{CD}^{2} 8^{-}$, and expressed cytoplasmic $\kappa$ light chain, indicating clonal plasma cells.

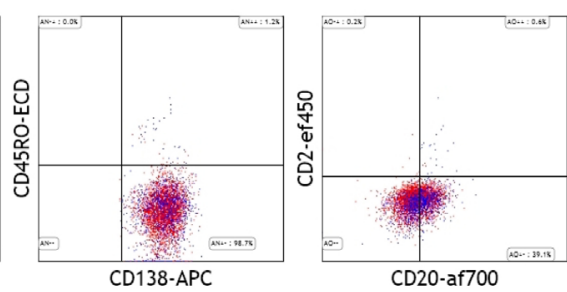

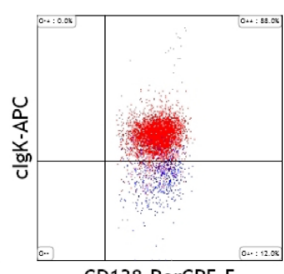

CD138-PerCP5.5

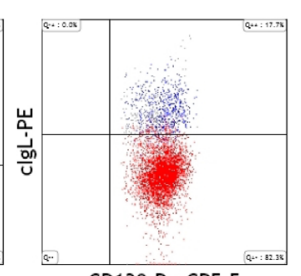

CD138-PerCP5.5
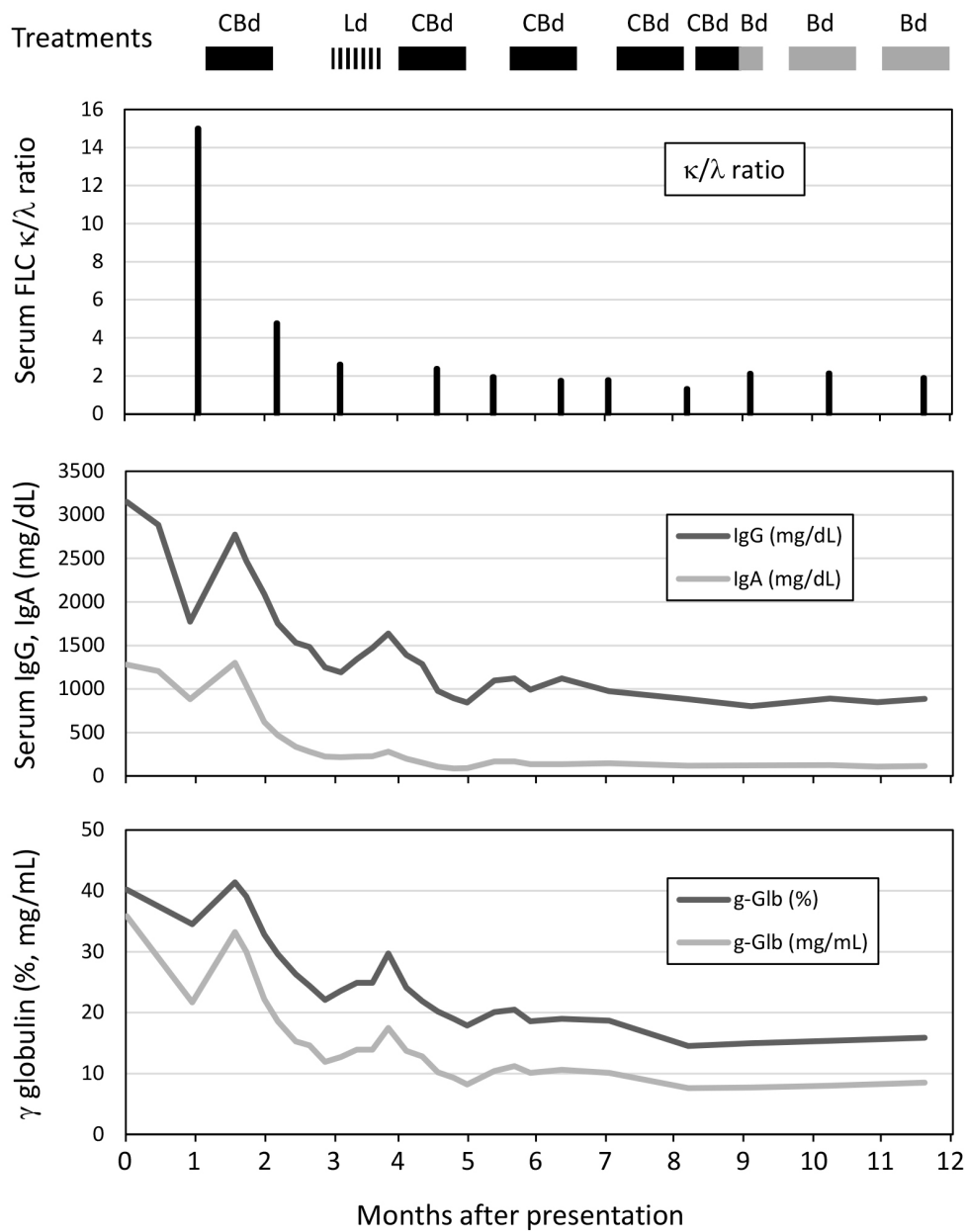

Figure 5. Course of the serum $\mathrm{FLC} \kappa / \lambda$ ratio, serum levels of $\lg G$ and $\lg A$, and percentages and calculated levels of $\gamma$ globulin during the first year of treatment. The treatments consisting of $\mathrm{CBd}$ (cyclophosphamide $300 \mathrm{mg} / \mathrm{m}^{2} \mathrm{PO}$, bortezomib 1.3 $\mathrm{mg} / \mathrm{m}^{2} \mathrm{SC}$, and dexamethasone $40 \mathrm{mg} \mathrm{PO}$ on days $1,8,15$, and 22 for a 5 -week treatment cycle), $\mathrm{Bd}$ (bortezomib $1.3 \mathrm{mg} / \mathrm{m}^{2} \mathrm{SC}$ and dexamethasone $40 \mathrm{mg}$ PO on days $1,8,15$, and 22 for a 5 -week treatment cycle), and Ld (lenalidomide $15 \mathrm{mg} \mathrm{PO}$ on days 1 to 21 and dexamethasone $20 \mathrm{mg} P O$ on days $1,8,15$ for a 4-week treatment cycle) regimens are indicated at the top. Ld was considered ineffective. 
sistent administration of bortezomib for $>2$ years, and laboratory data related to liver function improved, albeit marginally (Figure 6). The difference between involved FLC $-\kappa$ and uninvolved FLC- $\lambda$ (dFLC) became below the threshold of very good partial response (VGPR), i.e. $<40 \mathrm{mg} / \mathrm{L},{ }^{14}$ and the level was maintained for $>2$ years (Figure 6). The cumulative bortezomib dose for 2 years was $72.6 \mathrm{mg} / \mathrm{m}^{2}$. Significant complications of bortezomib were grade 2 diarrhea that occurred on the day of administration of the drug and grade 1 peripheral sensory neuropathy. Leukocytosis persisted during the course; there was no evidence indicative of myeloproliferative neoplasm.

\section{DISCUSSION}

We described here a female patient who presented with marked hepatomegaly with firm consistency. As the laboratory data demonstrated the pattern of polyclonal hypergammaglobulinemia and a low level of albumin, we initially considered liver cirrhosis. However, as we subsequently found amyloid deposits in multiple organs and clonal plasma cells in the BM, we correctively recognized that a plasma cell dyscrasia was underlying her condition. This report suggests that clinicians should consider hepatic involvement of AL amyloidosis in the differential diagnosis whenever a patient presents with unexplained hepatomegaly. Other characteristic features of this patient included spontaneous vertebral compres-

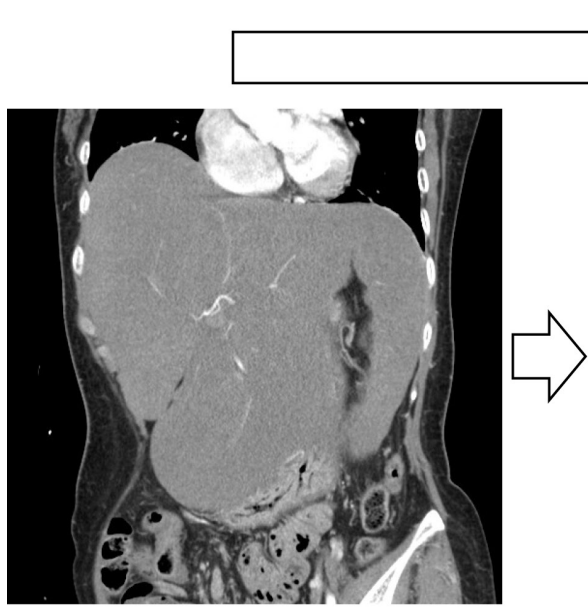

Before treatment

\section{Bortezomib-based chemotherapy}

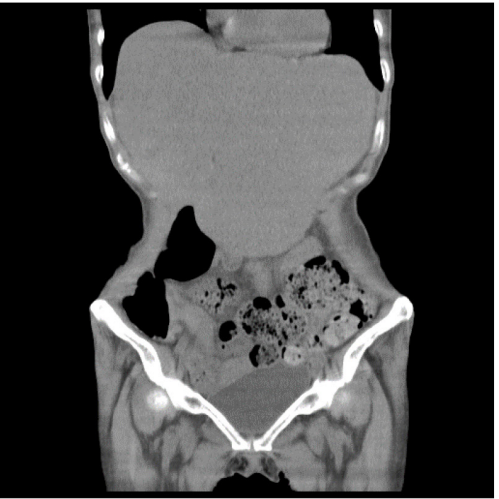

1 year after presentation

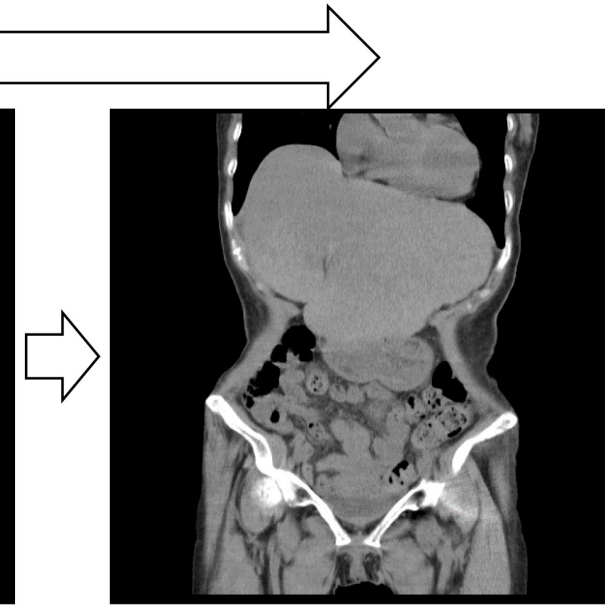

2 years after presentation

\begin{tabular}{|c|c|c|c|}
\hline & Before treatment & 1 year after presentation & 2 years after presentation \\
\hline Liver span (cm) & 24.2 & 18.8 & 17.4 \\
\hline FLC-к (mg/L) & $1,290.0$ & 24.7 & 42.3 \\
\hline FLC- $\lambda(\mathrm{mg} / \mathrm{L})$ & 86.0 & 13.0 & 21.3 \\
\hline $\mathrm{dFLC}(\mathrm{mg} / \mathrm{L})$ & $1,194.0$ & 11.7 & 21.0 \\
\hline Albumin (g/dL) & 2.7 & 3.2 & 3.3 \\
\hline Choline esterase (IU/L) & 72 & 153 & 143 \\
\hline Cholesterol (mg/dL) & 90 & 202 & 145 \\
\hline Alkaline phosphatase & 604 & 802 & 550 \\
\hline Prothrombin time (sec) & 16.9 & 16.4 & 15.8 \\
\hline
\end{tabular}

Figure 6. Response to bortezomib-based treatment for $>2$ years. Top pictures, coronal plane CT images of the abdomen, showing the reduction of liver size. Bottom table, parameters indicative of organ (hepatic) response and hematological response, in addition to laboratory data related to liver function. The response criteria: hepatic response in organ response, decrease in radiographic liver size by at least $2 \mathrm{~cm} ;{ }^{5}$ very good partial response in hematological response, dFLC $<40 \mathrm{mg} / \mathrm{L} .{ }^{14}$ 
sion fractures and the presence of Howell-Jolly bodies in the blood; the former has been described to be an initial presentation of AL amyloidosis in preferential association with hepatic and BM involvement and $\kappa$ lightchain, ${ }^{15}$ and the latter accounts for hyposplenism resulting from splenic involvement. ${ }^{4,6,7}$ On the other hand, $2 \%$ of cases in the Mayo clinic series $(n=474)$ had a $>20 \times$ $10^{3} / \mu \mathrm{L}$ white cell count; ${ }^{4}$ however, it is unclear whether leukocytosis is related to AL amyloidosis. Finally, quantitation of serum FLCs should be utilized as an adjunctive diagnostic modality that may demonstrate clonality in patients with AL amyloidosis who do not have monoclonal proteins by immunofixation. ${ }^{1,2,16}$ It should be noted, however, that the uninvolved FLC- $\lambda$ was not suppressed but elevated in the present case, presumably reflecting polyclonal gammopathy.

Polyclonal hypergammaglobulinemia or polyclonal increase of immunoglobulins is most often due to an infectious, inflammatory, or reactive process. In a retrospective cohort study $(\mathrm{n}=148)$ from the Mayo clinic, liver disease, including autoimmune and viral etiologies, was the most common pathology associated with this condition, followed by connective tissue disorders, chronic infection, hematologic disorders, and non-hematologic malignancies. ${ }^{17}$ The cause of polyclonal hypergammaglobulinemia is yet to be elucidated, but it is thought to be the result of dysregulation of the immune system and chronic stimulation; IL-6, IL-10, several cytokines, and $\mathrm{T}$ cell dysfunction may have been implicated. ${ }^{17}$ In the present case, where the liver parenchyma was heavily infiltrated by amyloid deposits, it is possible that the hypergammaglobulinemia reflected a reactive or inflammatory process against amyloid deposits in the liver, and the rapid decrease of the $\gamma$ globulin and immunoglobulin levels after the first cycle of chemotherapy was attributed to the anti-inflammatory effects of dexamethasone included in the chemotherapy regimen.

The outcome of patients with AL amyloidosis immediately depends on the spectrum and severity of organ involvement, especially on whether the heart is involved and to what extent. ${ }^{2,4}$ However, as the underlying abnormality in AL amyloidosis is clonal plasma cell proliferation, which is the source of the amyloidogenic lightchain deposition in the organs, long-term outcome depends on the plasma cell clone-related characteristics. ${ }^{18}$ Based on these considerations, the revised Mayo staging scheme includes two independent cardiac biomarkers (i.e. troponin $\mathrm{T}[\mathrm{TnT}]$ and N-terminal pro-brain natriuretic protein [NT-ProBNP] or BNP) and a plasma cell clone-related parameter, $\mathrm{dFLC}$, reproducibly stratifying the AL patients into four prognostic subgroups according to the presence or absence of these three risk factors. ${ }^{18}$ On the other hand, cytogenetic abnormalities have been reported to be associated with survival; in contrast to what has been observed in patients with multiple myeloma, ${ }^{19} \mathrm{t}(11 ; 14)(\mathrm{q} 13 ; \mathrm{q} 32) / C C N D 1-I G H$ is associated with adverse prognosis in patients with AL amyloidosis. ${ }^{20-22}$ Taken together, the current case, in which cardiac involvement was absent despite the modest increase of BNP, but the values of dFLC and FLC- $\kappa$ were higher than each cut-off and the clonal plasma cells carried the $\mathrm{t}(11 ; 14)$ (Table 1), ${ }^{18,20-23}$ was considered to be categorized into a high-risk group requiring rapid hematologic response.

The management of patients with $\mathrm{AL}$ amyloidosis, as well as the correct diagnosis of this complicated condition, requires multispecialty collaboration. ${ }^{1}$ The goal of treatment is to rapidly and maximally eliminate the production of the precursor protein (i.e. the clonal light chain) by targeting the underlying plasma cell clone. ${ }^{2}$ Bortezomib, which is the first proteasome inhibitor, in combination with dexamethasone and cyclophosphamide (designated as CyBorD) was first applied to patients with $\mathrm{AL}$ amyloidosis in two groups, demonstrating the hematological response rate of $94 \%$ and $81 \%$, respectively. ${ }^{24,25}$ In a larger study, in which a total of 230 patients with newly diagnosed AL amyloidosis were enrolled, the overall hematological response rate was $60 \%$ and cardiac or renal response was observed in proportions of the patients. ${ }^{26}$ In the current case, we found 
Table 1. Application of risk factors predicting survival of AL patients to this case

\begin{tabular}{|c|c|c|c|}
\hline Risk category & Risk factor & Reference no. & This case \\
\hline \multirow{2}{*}{ Cardiac biomarkers } & $\mathrm{TnT} \geq 0.025 \mathrm{ng} / \mathrm{mL}$ & 18 & Not available \\
\hline & NT-ProBNP $\geq 1,800 \mathrm{pg} / \mathrm{mL}$ or $B N P \geq 400 \mathrm{pg} / \mathrm{mL}$ & 18 & No \\
\hline \multirow{3}{*}{ FLC } & Clonal excess of light chain (FLC ratio $<0.26$ or $>1.65$ ) & 23 & Yes \\
\hline & $\mathrm{dFLC} \geq 180 \mathrm{mg} / \mathrm{L}$ & 18 & Yes \\
\hline & $\mathrm{dFLC} \geq 190 \mathrm{mg} / \mathrm{L}$, or $\geq 294 \mathrm{mg} / \mathrm{L}$ for $\kappa-A L$ patients or $182 \mathrm{mg} / \mathrm{L}$ for $\lambda$-AL patients & 23 & Yes \\
\hline \multirow{2}{*}{ Cytogenetics } & $\mathrm{t}(11 ; 14)(\mathrm{q} 13 ; \mathrm{q} 32) / C C N D 1-/ G H$ & $20,21,22$ & Yes \\
\hline & Abnormal FISH & 21 & Yes \\
\hline
\end{tabular}

consistent reduction of the liver size over two years in association with persistent hematological response. Taken together with sporadic case reports, in which marked liver response was seen, ${ }^{12,13,27}$ it is suggested that plasma cell-targeting therapy can reduce the amyloid deposits from the involved organs, potentially reversing their dysfunction.

\section{REFERENCES}

1. Kastritis E, Dimopoulos MA. Recent advances in the management of AL Amyloidosis. Br J Haematol 2016; 172:170-186.

2. Muchtar E, Buadi FK, Dispenzieri A, et al. Immunoglobulin light-chain amyloidosis: From basics to new developments in diagnosis, prognosis and therapy. Acta Haematol 2016;135:172-190.

3. McKenna RW, Kyle RA, Kuehl WM, et al. Plasma cell neoplasms. In: Swerdlow SH, Campo E, Harris NL, et al., eds. World Health Organization Classification of Tumours of Haematopoietic and Lymphoid Tissues. Lyon: IARC; 2008:200-213.

4. Kyle RA, Gertz MA. Primary systemic amyloidosis: Clinical and laboratory features in 474 cases. Semin Hematol 1995;32:45-59.

5. Gertz MA, Comenzo R, Falk RH, et al. Definition of organ involvement and treatment response in immunoglobulin light chain amyloidosis (AL): A consensus opinion from the 10th International Symposium on Amyloid and Amyloidosis, Tours, France, 18-22 April 2004. Am J Hematol 2005;79:319-328.

6. Gertz MA, Kyle RA. Hepatic amyloidosis (primary [AL], immunoglobulin light chain): The natural history in 80 patients. Am J Med 1988;85:73-80.
7. Park MA, Mueller PS, Kyle RA, et al. Primary (AL) hepatic amyloidosis: Clinical features and natural history in 98 patients. Medicine (Baltimore) 2003;82:291-298.

8. Hoffman MS, Stein BE, Davidian MM, et al. Hepatic amyloidosis presenting as severe intrahepatic cholestasis: A case report and review of the literature. Am J Gastroenterol 1988;83:783-785.

9. Cross TJ, Wendon JA, Quaglia A, et al. Myeloma associated amyloidosis presenting as subacute liver failure. Postgrad Med J 2006;82:e13.

10. Yamamoto T, Maeda N, Kawasaki H. Hepatic failure in a case of multiple myeloma-associated amyloidosis (kappa-AL). J Gastroenterol 1995;30:393-397.

11. Godskesen L, Abildgaard N, Kjeldsen J, et al. A rare cause of severe hepatomegaly with an improving outcome. BMJ Case Rep 2014; doi: 10.1136/bcr-2013-203360.

12. 板倉潤, 泉並木, 土谷 薰, 他 . 長期の Melphalan-prednisolone 療法により肝腫大の著明な改善を認めた原発性 アミロイドーシスの 1 例 . 肝臓 2001;42:243-248.

13. 蔹地啓市, 高橋祥一, 葉原隆泰, 他. M-Dex (melphalan-dexamethasone) 療法が奏功した肝アミロイドーシ スの 1 例 . 肝臓 2008;49:581-588.

14. Palladini G, Dispenzieri A, Gertz MA, et al. New criteria for response to treatment in immunoglobulin light chain amyloidosis based on free light chain measurement and cardiac biomarkers: impact on survival outcomes. J Clin Oncol 2012;30:4541-4549.

15. Wu X, Feng J, Cao X, et al. Atypical immunoglobulin light chain amyloidosis: Spontaneous vertebral compression fracture, liver involvement, and bone marrow involvement report of 3 cases and review of the literature. Medicine (Baltimore) 2016;95:e4603.

16. Dispenzieri A, Kyle R, Merlini G, et al. International Myeloma Working Group guidelines for serum-free light chain analysis in multiple myeloma and related disorders. Leukemia 2009;23:215-224. 
17. Dispenzieri A, Gertz MA, Therneau TM, et al. Retrospective cohort study of 148 patients with polyclonal gammopathy. Mayo Clin Proc 2001;76:476-487.

18. Kumar S, Dispenzieri A, Lacy MQ, et al. Revised prognostic staging system for light chain amyloidosis incorporating cardiac biomarkers and serum free light chain measurements. J Clin Oncol 2012;30:989-995.

19. Fonseca R, Blood EA, Oken MM, et al. Myeloma and the $\mathrm{t}(11 ; 14)(\mathrm{q} 13 ; \mathrm{q} 32)$; evidence for a biologically defined unique subset of patients. Blood 2002;99:3735-3741.

20. Bryce AH, Ketterling RP, Gertz MA, et al. Translocation $\mathrm{t}(11 ; 14)$ and survival of patients with light chain (AL) amyloidosis. Haematologica 2009;94:380-386.

21. Warsame R, Kumar SK, Gertz MA, et al. Abnormal FISH in patients with immunoglobulin light chain amyloidosis is a risk factor for cardiac involvement and for death. Blood Cancer J 2015;5:e310.

22. Bochtler T, Hegenbart U, Kunz C, et al. Translocation $t(11 ; 14)$ is associated with adverse outcome in patients with newly diagnosed AL amyloidosis when treated with bortezomib-based regimens. J Clin Oncol 2015;33:13711378.
23. Kumar S, Dispenzieri A, Katzmann JA, et al. Serum immunoglobulin free light-chain measurement in primary amyloidosis: Prognostic value and correlations with clinical features. Blood 2010;116:5126-5129.

24. Mikhael JR, Schuster SR, Jimenez-Zepeda VH, et al. Cyclophosphamide-bortezomib-dexamethasone (CyBorD) produces rapid and complete hematologic response in patients with AL amyloidosis. Blood 2012;119:4391-4394.

25. Venner CP, Lane T, Foard D, et al. Cyclophosphamide, bortezomib, and dexamethasone therapy in AL amyloidosis is associated with high clonal response rates and prolonged progression-free survival. Blood 2012;119:43874390.

26. Palladini G, Sachchithanantham S, Milani P, et al. A European collaborative study of cyclophosphamide, bortezomib, and dexamethasone in upfront treatment of systemic AL amyloidosis. Blood 2015;126:612-615.

27. 長町康弘, 山内尚文, 村松博士, 他. 自家末梢血幹 細胞移植後にボルテゾミブとデキサメサゾンの併 用療法で著明な肝腫大が改善した全身性 AL アミロ イドーシスを伴った BJP 型多発性骨髄腫。臨床血液 2015;56:323-328. 


\section{顕著な肝腫大と多クローン性高 $\gamma$ グロブリン血症で発症した AL アミロイドーシスの 1 例}

大野仁嗣 ${ }^{1}$, 戸田有亮 ${ }^{1}$, 鴨田吉正 ${ }^{1}$, 岡部 誠 ${ }^{2}$, 本庄 原 $^{3}$

${ }^{1}$ 天理よろづ相談所病院 血液内科

2 天理よろづ相談所病院 消化器内科

3 天理よろづ相談所病院 病理診断部

症例は 65 歳女性．顕著な肝腫大と多クローン性高 $\gamma$ グロブリン血症のため紹介受診した. 総蛋白 $8.9 \mathrm{~g} / \mathrm{dL}$ ， アルブミン $35.6 \%$ ，グロブリン $40.2 \%$ (35.8 mg/mL)，アルカリフォスファターゼ $730 \mathrm{IU} / \mathrm{L} . \mathrm{CT}$ 上で計測した頭尾 側方向の肝の長さは $24.2 \mathrm{~cm}$ であった. 肝生検では，肝実質は好酸性の無構造の物質に置換され，それはコンゴー レッド染色陽性，偏光䫓微鏡下で apple green の複屈折を示し，アミロイド沈着であることが判明した. アミロ イド沈着は胃粘膜と骨髄にも認められた．免疫固定法では血清・尿中に M 成分を認めなかったが，血清遊離軽鎖 (free light chain, FLC) は $K$ 鎖に著しく偏倚していた (FLC- $K, 1,290$ mg/L; FLC- $\lambda$ ， 86 mg/L). 骨髄ではクローン性 の形質細胞を $10.4 \%$ 認め，FISH で C CND1 遺伝子と免疫グロブリン重鎖遺伝子の融合シグナルを認めた. AL アミ ロイドーシスと診断し，ボルテゾミブを含む化学療法を開始したところ速やかに血液学的効果を認め，very good partial response の効果判定基準を満たした. 肝腫大は 2 年以上にわたるボルテジミブの投与によって徐々に縮小 した．初診時の多クローン性高 $\gamma$ グロブリン血症は，肝でのアミロイド沈着に対する反応性・炎症性過程を反映 していたと考えられる．形質細胞を標的とした治療は臓器のアミロイド沈着を減少させ，低下した機能を回復さ せる可能性がある.

キーワード : AL アミロイドーシス，肝アミロイドーシス，血清遊離軽鎖，多クローン性高 $\gamma$ グロブリン血症， ボルテゾミブを含む化学療法 